\title{
Discursive Constructions of the African National Congress (ANC) and Its Discourse of Freedom: A Critical Analysis
}

\section{Mr Teboho Pankratius Bojabotseha}

\author{
Vaal University of Technology, Faculty of Human Sciences, Vanderbijlpark, 1900, South Africa \\ Email: tebohog@vut.ac.za
}

\section{Prof. Kholeka Constance Moloi}

Vaal University of Technology, Faculty of Human Sciences, Vanderbijpark, 1900, South Africa

Email: conniem@vut.ac.za

Doi:10.5901/ajis.2014.v3n4p93

Abstract

This paper interrogates the various discursive or symbolic constructions or presentations of the African National Congress (ANC) contained in the 1999, 2004 and 2009 ANC national election manifestos and the ruling party's discourse of freedom. The term discursive construction is used to capture the structural, systemic, cultural and epistemological patterns of hegemonic power that have engulfed the ANC discourse since 1994. We argue that the ANC is discursively constructed or presented as an organisation which brought freedom to South Africa; a leader of the struggle for change; an organisation still committed to the policies of the Reconstruction and Development Programme (RDP) and principles of the Freedom Charter; the only force in South Africa with experience of democratic government; the only organisation with plans or programmes to transform South Africa into a non-racial, non-sexist and prosperous democracy; and lastly, a mass-based organisation, rooted amongst the people, reaching into every social sector and every corner. An integral part of this narrative is a discourse of "complete" or "total" freedom - in the sense that it includes the social, economic and political aspects or elements of the reality of the lives of the majority of South Africans - which the ruling party in South Africa claims to have delivered for the majority of South Africans. All these symbolic constructions or presentations, including the ANC's discourse of "complete" or "total" freedom, are negated by reality as well as by alternative oppositional and academic discourse about what has really been achieved in the country since 1994.

Keywords: Discursive and symbolic constructions, African National Congress (ANC), manifestos, discourse of freedom

\section{Introduction}

The ruling party in South Africa, the African National Congress (ANC), recently celebrated its 102-year anniversary. On this occasion, it not only presented its January 8 Statement, but also unveiled its 2014 national election manifesto. Formed on 8 January 1912 in Bloemfontein (ANC 2010: 1; McKinley 1997: 6), the ANC is undoubtedly the oldest liberation movement in Africa and the "most popular" political party in South Africa as shown by the outcomes of the national general elections held in April 1994, June 1999, April 2004 and April 2009. In the 1994 national elections the ANC received a majority of almost two-thirds (Friedman 1999: 97; Lodge 1994: 38). More specifically, at national level the ANC obtained 62,5 percent of the vote, taking $12,237,655$ of the total of 19,530,498 valid votes cast and thus gaining 253 seats in the 400-seat National Assembly (Meredith 1994: 184-185; Reynolds 1994: 183). In the June 1999 national elections the ANC won a sweeping victory. It received 66, 4 percent of the vote, taking 10,601,330 of the total of 15,977,143 valid votes cast and thus gaining 266 seats in the National Assembly (Lodge 1999: 167; Reynolds 1999: 175). On 14 April 2004 the ANC was elected with an increased majority. It received 69, 7 percent of the vote, taking $10,880,915$ of the total of $15,612,671$ valid votes cast and thus gaining 279 seats in the legislative assembly (IEC 2004: 1). Lastly, the outcomes of the fourth national general elections, held on 22 April 2009, are also significant. In these elections the ANC received 65,9 percent of the vote, taking 11,650,784 of the total of 17,680,729 valid votes cast and thus gaining 264 seats in the National Assembly (EISA 2009: 1; IEC 2009: 1).

This paper, however, is concerned not so much with the age and popularity of the ruling party in South Africa but with a critical analysis of the discursive or symbolic constructions or presentations of the ANC and its discourse of "complete" or "total" freedom, evident in the 1999, 2004 and 2009 national election manifestos. Our central contention is 
that the ANC is discursively or symbolically constructed or presented as an organisation which brought freedom to South Africa; a leader of the struggle for change; an organisation still committed to the policies of the Reconstruction and Development Programme (RDP) and the principles of the Freedom Charter; the only force in South Africa with experience of democratic government; the only organisation in South Africa with plans or programmes to transform the country into a non-racial, non-sexist and prosperous democracy; and lastly, a mass-based organisation rooted amongst the people, reaching into every social sector and every corner of the land (ANC 1999; 2004; 2009).

An integral part of this narrative in the three texts is the ANC's discourse of freedom. In this discourse, freedom is discursively or symbolically constructed or presented as "complete" or "total" freedom in the sense that it involves social, economic and political aspects or elements of the reality of the people in South Africa. By focusing particularly on the discursive construction of the ANC (i.e. sameness, power, liberator) this paper employs a discourse-historical analytical method. We argue that the various discursive or symbolic constructions or presentations of the ANC, which serve an ideological function of reproducing dominant political relations in South Africa, are challenged and even negated by reality. Thus, the ANC's discourse of complete or total freedom faces serious challenge and is even negated by alternative oppositional and academic discourse about what was really achieved in 1994.

We will show in our argument how the ANC employs particular linguistic devices to construct sameness and uniqueness on the one hand, and difference from other political parties on the other. In this regard, we make the point that the ANC has historically served and continues to serve as a polemical argument for the West's desperate desire to assert its difference from other political organisations (Ndlovu-Gatsheni 2013:102). According to Chapman (1996:136), the distinctive features of South Africa's layers of difference are that identities have always been either too fragmented or too solid to permit utterly bipolar conflict. He goes on to say that our transformation is a paradox. Despite division, difference and sectional loyalties, integration of the economy, even of culture, proceeds through the failure of alliances (ANC, COSATU, SANCO, SACP) and allegiances to be anything but multiple, relatively inconsistent and finally, impotent.

\section{Literature Review}

There is an abundance of literature about election manifestos. For example, the literature reviewed by Bojabotseha and Moloi (2014) indicates the existence of polarised views on the value of party election manifestos, with a number of negative views. Chouliaraki and Fairclough (1999: 21) have argued that the party election manifestos serve as "shifting articulations of symbolic/discursive resources (such as genre, discourse, voices) which themselves come to be articulated into relative permanence as moments of discourse and transformed in that process". Like other manifestos, they present "strategic direction and outlines of prospective legislation" (Scruton 1982: 358) to be expected in the event that the organisation receives enough votes from the electorate to serve in government.

Discourse, like many other concepts in the human and social sciences such as "ideology", "power", "hegemony" and "language", is difficult to define. Fairclough (1992: 3-4) attributes this difficulty to the "many conflicting and overlapping definitions formulated from various theoretical and disciplinary standpoints". The South African Concise Oxford Dictionary (SACOD) (2002: 332), for instance, defines discourse simply as "written or spoken communication or debate". Defined in this manner, discourse is indistinguishable from language since the latter, as a method of communication, has a written or spoken form. For McCann and Minichiello (2010: 221), discourse refers to "commonly held beliefs that underpin a topic; the authorised accounts about it" where these beliefs "contain indicators of power that shape how we interact with concepts such as race, class, gender, sexuality and othering".

McCann and Minichiello's (2010) definition is very similar to that of ideology. The only notable difference is that, with ideology, it is "a system of ideas" (SACOD 2002: 573), rather than a "system of beliefs", which forms the basis of a topic. According to Fairclough (1992: 128), discourse represents a particular way of constructing a subject matter. It is that "sort of language used to construct some aspect of reality from a particular perspective, for example the liberal discourse of politics" (Chouliaraki and Fairclough 1999: 63). In the context of this paper, discourse refers to the language that the ANC uses discursively to construct its identity as the liberator of all South Africans. Thus, the discursive construction of the ANC is a continuous process, a complex state of being and becoming, mediated through and through by spatial, agential, structural, historical and contingent variables (Ndlovu-Gatsheni, 2013:100). In a later work, Fairclough (2003: 124) provides a revised and extended definition according to which discourses are "ways of representing aspects of the world - the processes, relations and structures of the material world, the mental world of thoughts, feeling, beliefs and so forth, and the social world". Through these representations, the ANC articulates its own norms, develops a selfimage and this image is integrated into the set of signifiers asserting what is supposed to be its identity politically, economically and socially (Ndlovu-Gatsheni, 2013:100). The value of this revised and extended definition of discourse 
lies, firstly, in its recognition of the plurality of discourse. Secondly, it expresses the fact that the subject matter or aspect of reality that is constructed or presented can take on many forms, especially the form of processes, relations and structures. Lastly, it incorporates the idea that the world to which these processes, relations and structures belong may be material, mental, social, political, historical, cultural or economic. Discourse in this sense is close to Pierre Bourdieu's notion of habitus as explained by (De Cillia, Reisigl \& Wodak, 2011). Habitus refers to a complex of common ideas, concepts or perception schemes (a) of related emotional attitudes intersubjectively shared within a specific group of persons, (b) as well as of similar behavioural dispositions, (c) all of which are internalised through national socialisation (De Cillia et al., 2011:153).

Fairclough (2003: 124) further claims that discourses not only represent the world as it is or as it is seen to be, but may also be "projective, imaginaries, representing possible worlds which are different from the actual world, and tied in to projects to change the world in particular direction". In Texts and Discourse: A framework for the production of meaning, Williams (1993: 346) suggests that discourses are also "disciplines that order the way in which bodies of texts are produced, circulated and received; but also within which human and inanimate bodies are ordered". When discourse is seen as a body of knowledge, it is possible then to talk about, for example, the discourse of apartheid, the discourse of capitalism, the discourse of civilians and the military, the discourse of totalitarianism (Williams 1993: 343-363), the state discourse of xenophobia, the discourse of exceptionalism, the discourse of indigeneity, et cetera (Neocosmos 2008). What follows below is a discussion of the various discursive constructions or presentations of the ruling party in South Africa in the 1999, 2004 and 2009 ANC national election manifestos.

\subsection{Discursive or symbolic constructions or presentations of the ANC}

There are various discursive or symbolic constructions or presentations of the ANC in the 1999, 2004 and 2009 national election manifestos. These constructions or presentations are not merely limited to the ones found in Bojabotseha and Moloi's (2014: 320-321) discussion. In the three texts under consideration, the ANC is discursively constructed or presented as (1) an organisation which brought freedom to South Africa; (2) a leader of the struggle for change; (3) an organisation still committed to the policies of the RDP and principles of the Freedom Charter; (4) the only force with experience of democratic government; (5) the only organisation in South Africa with plans to transform South Africa into a non-racial, non-sexist and prosperous democracy; and lastly, (6) a mass-based organisation rooted amongst the people, reaching into every social sector and every corner of the land. In this regard, the ANC's discursive construction is rooted in identity politics that focus upon self-interest and perspectives and ways in which people's politics may be shaped by aspects of their identity through race, class, religion, gender, ethnicity, ideology, nation, culture and currency (Chapman 1996).

\subsubsection{An organisation which brought freedom to South Africa}

The ANC is discursively constructed or presented as the organisation which removed the evil system of apartheid which existed in South Africa prior to 1994 and replaced it with a system of freedom and democracy. The fourth paragraph of the Message of the President of the ANC in the 1999 national election manifesto states:

Five years ago, you elected a government of the people to begin removing the terrible system of apartheid. In these short five years, your government, led by the ANC, has created a new legacy of freedom and democracy (ANC 1999: 1).

According to this narrative the ANC brought freedom and democracy to South Africa when it defeated the apartheid system in April 1994. In its 1999 national election manifesto, the ANC contends:

The ANC led the fight for freedom, acting together with its alliance partners and the great majority of South Africa. With the overwhelming support of the people, the ANC defeated apartheid in 1994 ... (ANC 1999: 3).

This symbolic construction or presentation of the ANC as the only organisation which brought freedom to South Africa is flawed. Following Bojabotseha and Moloi (2014: 320-321), it excludes the contribution of other political organisations and formations in South Africa and the world over and countless people who sacrificed their lives in the struggle for the liberation of South Africa from colonial oppression and imperialist exploitation. In the same vein, Ellis (2014: 3) declares the discursive construction of the ANC as an organisation which brought freedom to South Africa as "an outright lie". In his view, the "truth" is that the downfall of the apartheid system was the work of many other social formations nationally, regionally and internationally (Ellis 2014: 3). In affirmation of Ellis' viewpoint, the ANC, to some extent, acknowledges the contribution of its alliance partners (the South African Communist Party (SACP), the Congress 
of South African Trade Unions (COSATU) and the South African National Civic Organisation (SANCO)) and the great majority of the people of South Africa in the fight for a non-racial, non-sexist, democratic and prosperous South Africa.

\subsubsection{A leader of the struggle for change}

The ANC is discursively constructed or presented also as a leader of the struggle for change in South Africa. In this presentation, change is achieved through the provision of services such as access to water, electricity, health and quality education and through the redress of past imbalances in many areas of people's lives. The following statement in the ANC's 1999 national election manifesto is worth considering:

Since 1994, the ANC has been leading a vast process of change. Guided by the Reconstruction and Development Programme (RDP), the ANC has brought water, electricity and telephone lines to millions of South Africans. Houses are being built. Health and education are being made available to all (ANC 1999: 4).

Indeed, these services have improved for the majority of black people in the country. However, 20 years into democracy, those who live in rural areas and in the impoverished sites within urban areas still have insufficient or no services at all. Several strikes and demonstrations by these communities have taken place since President Jacob Zuma's state of the nation address on 14 February 2014. In protests throughout the country, tyres are being burnt and shops looted, and in one of the municipalities in the Gauteng province, essential service sites such as a clinic, police station and library were burnt down. Dr Mangosuthu Buthelezi, president of the Inkatha Freedom Party has criticised the ANC for having taught its followers to burn down property in an attempt to make the country ungovernable.

In its 2004 national election manifesto, the ANC maintains:

The change that happened 10 years ago was a result of struggle and sacrifice, led by the African National Congress (ANC), it was change that created an opportunity for us to chart our future together (ANC 2004: 3).

The ANC concludes its 2004 national election manifesto by assuring the audience that "it speaks with confidence because it has been at the head of this national effort to change our country for the better ..." (ANC 2004: 10). In its 2009 national election manifesto, the ANC similarly contends: "for over 97 years, it has led the struggle to bring about a South Africa that belongs to all our people, black and white" (ANC 2009: 2). Although the ideal today might be post-apartheid South African nationals, many rural Africans cannot be sure, for example, where the power of the government characterised as non-racial and democratic - ends and where the power of the chief - local and ethnic - begins (Chapman 1996).

\subsubsection{An organisation committed to the RDP and the Freedom Charter}

The ANC is symbolically constructed or presented as an organisation which is still committed to the policies of the RDP and the principles of the Freedom Charter. In the 2004 national election manifesto the RDP is alluded to as "a programme which continues to guide the ANC's vision - Vision 2014 - to build a society that is truly united, non-racial, non-sexist and democratic" (ANC 2004: 6). In the 2009 ANC national election manifesto the vision of the Freedom Charter is invoked as "the guiding principle which underpins the ANC's programme to transform South Africa" (ANC 2009: 1). The vision of the Freedom Charter to unite a nation of many languages and cultural, religious and socio-economic diversity is also presented in the 2009 national election manifesto as "the inspiration of the country's Constitution", adopted in 1996 (ANC 2009: 1). The symbolic construction or presentation of the ANC as an organisation still committed to the policies of the RDP is, however, falsified by the fact that the goals of the RDP were in fact abandoned one by one and new priorities were formulated in the government's macro-economic policy framework, the Growth, Employment and Redistribution (Gear) programme (Kagarlitsky 1999). The RDP was replaced by Gear in June 1996 (EISA 2011; Harris 1997). The adoption of the Gear programme in June 1996 was in fact a culmination of the ANC's embrace of the American ideologies of neoliberal globalism and market fundamentalism (Terreblanche 2012: 65). Terreblanche (2012: 65) cites Ashman, Fine and Newman (2011), who postulate that:

The [ANC] government's adoption of the non-negotiable Growth, Employment and Redistribution programme (Gear) in 1996 signalled the crude resolution of any conflict over policy and the full embrace of neoliberalism. Gear emphasised fiscal austerity, deficit reduction and pegging taxation and expenditure as fixed proportions of the GDP [Gross Domestic Product]. Through Gear, the government's stated macro-economic priorities became the management of inflation, the deregulation of financial markets, tariff reduction and trade liberalisation as well as limiting government expenditure. The irony is that while the rationale for these policies was to attract direct foreign investment, their actual effect was to increase the outflow of domestic capital. 
The symbolic construction of the ANC as an organisation still committed to the principles of the Freedom Charter does not fare any better. An inter-textual and inter-discursive examination of the 1999, 2004 and 2009 ANC national election manifestos (Bojabotseha and Moloi, forthcoming) unambiguously indicates that the three texts merely reproduce and invoke both the RDP and the Freedom Charter. The reproduction and invocation of the RDP and especially the Freedom Charter at appropriate places in the three texts takes the form of quotations, without quotation marks, of relevant headings and clauses. This is done solely to lend credence and an authoritative voice to the ANC and to project continuity, rather than change, in the policy direction and trajectory of the ANC.

\subsubsection{An organisation with plans/programmes to transform South Africa into a non-racial, non-sexist and prosperous democracy}

In the same vein, there is a discursive construction or presentation of the ANC as an organisation with plans/programmes to transform South Africa in accordance with its vision of a non-racial, non-sexist, prosperous and democratic South Africa. In the 1999 national election manifesto, the programme of the ANC focused on speeding up delivery of basic needs and developing human resources. It also gave attention to building the economy of the country and creating jobs for the unemployed. Attention was also dedicated to combating crime and corruption; transforming the state; and building a better Africa and a better world (ANC 1999: 14). The 2004 ANC national election manifesto focused on "a growing economy; sustainable livelihoods; access to services; comprehensive social security; crime and corruption; constitutional rights and governance; and Africa and the world" (ANC 2009: 7-9). Lastly, the 2009 ANC national election manifesto identified five priority areas which the ANC promised to tackle with all the means at its disposal. These included the "creation of decent work and sustainable livelihoods; education; health; rural development, food security and land reform; and the fight against crime and corruption" (ANC 2009: 6). In its 2014 election manifesto, the ANC boasts the following achievements since 1994:

- From 1994 to the onset of the 2008 global financial crisis, we had the longest recorded period of uninterrupted economic growth, growing at twice the rate of the last 19 years of apartheid.

- Since 1994, five million more people are in work, with total employment at 14 million.

- Twice as many young people attended university and twice as many graduated in 2012 than in 1994.

- More than 1.4 million students have benefited from the National Student Financial Aid Scheme.

- The Public Works and Community Work programmes have created 6 million work opportunities for unemployed people, $40 \%$ of them young people.

- Nearly 5,000 farms have been transferred to black people, benefiting over 200,000 families.

- Nearly 80,000 land claims have been settled and 1.8 million people have benefited.

- The number of people receiving social grants increased from 3 million to 16 million.

- Over 3.3 million free houses have been built, benefiting more than 16 million people.

- About 12 million households have access to electricity, 7 million more than in 1994.

- Around $92 \%$ of South Africans have access to potable water, compared to 60\% in 1996.

Twenty years ago we began a journey to eradicate the legacy of apartheid. It has been 20 years of freedom and democracy. The lives of our people have vastly improved and South Africa is a much better place than it was before 1994. Over the last five years, the ANC has worked together with all South Africans to do more to fight poverty and unemployment and reduce inequality. Despite the negative global economic situation, we (ANC) have built on the social gains achieved since 1994. More of our people have been lifted out of extreme poverty; we have created more jobs than before; expanded social grants, housing and basic services to our people; and further improved access to better education and health care. Yet the challenges facing our country are immense. Poverty, inequality and unemployment still affect the lives of many people. Corruption continues to erode our social fabric and undermine our development efforts. Our economy continues to feel the effects of the global economic slowdown (ANC 2014 Election manifesto1).

\subsubsection{A mass-based organisation}

Lastly, there is a discursive or symbolic construction or presentation of the ruling party in South Africa, the ANC, as a mass-based organisation rooted amongst the people, reaching into every sector of society and every corner of the land. Of all the political formations in South Africa, the ANC is, according to Netshitenzhe 2012: 6), indeed "the only one which has located, after so many years of existence, the sweet-spot of one-million members and more". This "sweet-spot" prompted Netshitenzhe to ask whether the ANC should not declare 2012-2022, the first ten years of its second century, 
the "Decade of the Cadre", so that it could clean up and improve quality (Netshitenzhe: 2012: 6). This "pervasive view" of the ANC comes as no surprise. The application of the Althusserian framework to the South Africa context shows that the ruling party, because of its hold over state power and state apparatus1, ensures its continued ability to influence or control not only the means of production and the institutions through which laws of this country are made and applied, but also to exercise influence or control over the vast majority of the population in South Africa. In fact, the hold that the ANC - as opposed to other political formations - has over state power and the two types of state apparatus (the repressive state apparatus and ideological state apparatuses), and what it is able to do because of this hold, has been used as a plausible explanation for the creation of a situation of "systematic asymmetrical power relations" in South Africa (see Bojabotseha 2013). Terreblache's (2012: 82-83) discussion on the "limitations of a democratic system in a developing country with a large part of the population which is impoverished and 'underdeveloped' and the influence of these conditions on the population's capacity to make a 'contemplative choice between different political parties during elections"' is also worth noting. The fundamental point is that the majority of South Africans are too poor and "uneducated" to enjoy the luxury of making choices between "valuable goods". Many South Africans are essentially preoccupied with one choice in life: that is, how to stay alive (Terreblanche 2012: 83).

\section{The ANC's Discourse of Freedom}

The ANC's 1999, 2004 and 2009 national election manifestos reflect a discourse of freedom. More specifically, all three texts contain a particular discursive construction or presentation of freedom, a subject matter or aspect of the reality of the lives of the majority of South Africans. Scruton (1982: 180) draws a distinction between negative freedom and positive freedom. The former is conveyed in the expression "freedom from" and the latter is conveyed in the expression "freedom to". From what has been said, positive freedom refers to a state in which a person has powers to satisfy his/her needs. We argue that both negative freedom and positive freedom are invoked in the 1999, 2004 and 2009 ANC national election manifestos. A quick reading of these texts immediately creates an impression that the apartheid system, which was in place before 1994 and subsequently dismantled by the ANC-led government, functioned for decades as an institutionalised system of socio-economic and political constraints and threats for the black majority of South Africans. It subjected the black majority of South Africans to, amongst other constraints and threats, political oppression, economic exploitation and subjugation to a white minority. No wonder it was regarded as an immoral and inhumane system. In fact, it was described as a "crime against humanity" in resolution 2202A (16 December 1966) of the United Nations General Assembly (Dugard 2008: 1).

With the democratic elections of 1994, South Africa launched itself as a new liberal constitutional democracy in which the majority of South Africans enjoyed freedom(s) from the institutional constraints and threats which characterised the bygone system of apartheid. In fact, South Africa's new identity included a progressive liberal constitution which continues to provide three spheres of government - national, provincial and local - all compelled to work together for "effective, transparent, accountable and coherent government for the Republic as a whole" (The Constitution of the RSA 1996: 25). This constitution also allows the majority of South Africans positive freedom(s) in the form of the extensive range of individual, collective and socio-economic rights enshrined in the Bill of Rights. So, when the ANC or the ANC-led government is discursively constructed or presented as an organisation or a government which removed the system of apartheid and created a foundation for freedom and democracy, it actually set the stage for the majority of South Africans to exercise both negative and positive freedoms.

In the three texts, however, freedom is symbolically constructed or presented as "complete" or "total" freedom in the sense that it includes social, economic and political aspects or elements of the reality of the lives of the majority of South Africans. Since the ANC-led government is symbolically constructed or presented as a government which not only removed the apartheid system but also replaced it with a system of freedom and democracy, it follows that the freedom brought by ANC-led government comprised social, economic and political freedom. In the 2004 national election manifesto, the ANC contends:

We have, in these ten years, brought water and electricity to millions of households; built houses accommodating millions of South Africans; opened up access to quality education; removed discrimination in access to professions; turned the economy around to become more productive and globally competitive; and placed South Africa in a strategic

\footnotetext{
${ }^{1}$ Althusser (1971) draws a distinction between state power, whose seizure and conservation by a class or an alliance of classes or class
} fractions, is the object of political class struggle, and state apparatus, whose use is a function of class objectives. 
position to deal with international affairs (ANC 2004: 1).

A similar statement is found in the ANC's 2009 national election manifesto:

The ANC-led government has made much progress in the past 15 years, in the provision of housing, water and electricity to millions of homes. Our economy has grown, more jobs have been created than in any other time in our history and we have deepened our democracy. We have extended social protection to millions of South Africans through the provision of social grants (ANC 2009: 1).

In the two statements cited above, housing, water, electricity, education and social grants may be seen as constituting social aspects of complete or total freedom. The growth of the economy, the creation of more jobs and the establishment of a productive and globally competitive economy may be seen as constituting the economic aspects of complete or total freedom, whereas the removal of discrimination and the deepening of democracy are related to the political aspects of complete or total freedom. Even the discussion of the various programmes, together with the associated practical steps or measures which the ANC promises to undertake to realise its vision of a non-racial, nonsexist, democratic and prosperous South Africa (ANC 1999: 14-21; ANC 2004: 7-10; ANC 2009: 6-15), include the social, economic and political aspects of the discourse of complete or total freedom. This discourse is not only an integral part of the politics in South Africa, but actually part of the global dominant hegemonic neo-liberal discourse of politics.

\section{Alternative Oppositional and Academic Discourse of Freedom}

The ANC's discourse of complete or total freedom is, however, seriously challenged and, in some respects, seemingly negated by alternative oppositional and academic discourses - which are silenced, not heard of or completely ignored in the manifestos - about what was really achieved with the democratic elections of 1994, 1999, 2004 and 2009. Webster and Adler (2001: 121) cite Saul (1996), who maintains that the transition to democracy in South Africa "left intact the pillars of the capitalist market economy; it was a transition in the political system, not in the political economy". In other words, what was achieved by the ANC-led government in the first democratic national elections of 1994 is political freedom, but not social and economic freedom. Webster and Adler (2001) provide additional pointers to the alternative discourse of an "incomplete freedom" - that is, a freedom which is constituted only of the political aspects of the reality of the majority of South Africans. According to them (2001: 121), the economic policies adopted by the ANC-led government - more especially the Growth, Employment and Redistribution Policy Framework (GEAR), the macro-economic policy framework which replaced the Reconstruction and Development Programme (RDP) in 1996 - demonstrate considerable continuity with economic policies used by the apartheid regime prior to 1994. The ANC is also shown to have once embraced privatisation as a "fundamental principle", together with the gradual elimination of exchange controls and the reduction of tariffs to encourage export-led growth (Webster and Adler 2001: 121).

The ANC itself does not seem to be averse to the alternative oppositional discourse of an "incomplete freedom" as characterised above. In the document entitled Second Transition? Building a national democratic society and the balance of forces in 2012, prepared for discussion at its 2012 National Policy Conference, the ANC puts forward a vision which is suggestive of the view that the first transition was actually a political transition as it focused only on democratisation. In this discussion document the ANC in fact proposes the "need for a vision for a second transition that must focus on the social and economic transformation of South Africa over the next 30 to 50 years" (ANC 2012: 4).

Furthermore, a critical examination of the socio-economic conditions in South Africa indicates that, despite the remarkable achievements on the political front, the plight of the marginalised and poor has not changed dramatically (Blignaut 2013: 39). Suffice it to say that South Africa has serious challenges of poverty, unemployment and inequality (PUI) which continue to define the lived experience of the majority of the population of South Africa. In the 2009 national election manifesto, the ANC admits that:

Many households and communities, especially single-headed and child-headed households, remain trapped in poverty ... Unemployment is unacceptably high among our people ... Inequality has persisted and increased in our society (ANC 2009: 5).

\section{Conclusion}

In the 1999, 2004 and 2009 national election manifestos the ANC is variously discursively or symbolically constructed or presented as an organisation which brought freedom to South Africa; a leader of the struggle for change; an organisation still committed to the policies of the RDP and principles of the Freedom Charter; the only force with experience of democratic government; the only organisation in South Africa with plans or programmes to transform South Africa into a 
non-racial, non-sexist and prosperous democracy; and lastly, a mass-based organisation rooted amongst the people, reaching into every social sector and every corner of the land. An integral part of this narrative is a discourse of complete or total freedom in the sense that it includes social, economic and political aspects or elements of the reality of the lives of the majority of South Africa. Consequently, the ANC becomes the organisation which brought social, economic and political freedom to South Africa. However, we argued that these various symbolic constructions or presentations of the ANC are negated by reality and that the discourse of complete or total freedom is challenged and seemingly negated by alternative oppositional and academic discourse - silenced, not heard of or completely ignored in the three manifestos which contends that what was achieved in 1994 was actually an "incomplete" freedom, concerned only with political liberty.

\section{References}

African National Congress (ANC). 1999. 1999 Manifesto. [Online] Available: http://www.anc.org.za/elections/manifesto/manifestotext.txt (May 31, 2010)

African National Congress (ANC). 2004. 2004 ANC Manifesto. [Online] Available: http://www.anc.org.za/elections/2004/manifesto Imanifesto.html (May 31, 2010)

African National Congress (ANC). 2009. 2009 ANC Manifesto. [Online] Available: http://www.anc.org.za/elections/2009/ manifesto/manifesto.html (May 31, 2010)

African National Congress (ANC). 2010. Umzabalazo: A history of the African National Congress. [Online] Available: http://www.anc.org. za/ancdocs/about/mzabalazo.html (May 31, 2010)

African National Congress (ANC). 2012. The Second Transition? Building a national democratic society and the balance of forces in 2012. A discussion document towards the National Policy Conference, Version 7, as amended by the Special NEC, 27 February 2012. [Online] Available: http://www.anc.org/docs/discuss/2012/transition.pdf (August 8, 2013)

African National Congress (ANC). 2014. 2014 Election manifesto. [Online] Available: http://www.anc.org. za/elections/2014/manifesto/manifesto.html (February 20, 2014)

Althusser, L. 1971. Lenin and Philosophy and Other Essays. London: New Left Books.

Ashman, S; Fine, B \& Newman, S. (Eds.). 2011. The Crisis in South Africa: Neoliberalism, financialisation and uneven and combined development. Socialist Register.

Blignaut, S. 2013. Teaching for Social Justice in South African Universities. In G. de Wet (Ed.). Beyond the Apartheid University: Critical voices on transformation in the university sector. Alice, Eastern Cape, South Africa: University of Fort Hare, pp.36-51.

Bojabotseha, T.P. 2013. The Use of Language by the African National Congress to Position Itself as More Fit to Govern than Other Political Parties in South Africa. (Unpublished MPhil Thesis, University of Stellenbosch).

Chapman, M. 1996. The politics of identity: South Africa, storytelling, and literary history. South African Literatures. Short stories. Selected and introduced by Michael Chapman. London: Furore.

Bojabotseha, T.P. \& Moloi, K.C. 2014. A Critical Analysis of the African National Congress's Dominant Hegemonic Liberal Discourse. Mediterranean Journal of Social Sciences, 5:313-323.

Bojabotseha, T.P. \& Moloi, K.C. (Forthcoming). A Critical Discourse Analysis of Intertextuality and Interdiscursivity in the African National Congress.

Chouliaraki, L \& Fairclough, N. 1999. Discourse in Late Modernity: Rethinking critical discourse analysis. Edinburgh: Edinburgh University Press.

De Cilla, R.; Reisigl, M. \& Wodak, R. 2011. Discursive construction of national identities. Discourse \& Society. London: Sage Publications.

Dugard, J. 2008. Convention on the Suppression and Punishment of the Crime of Apartheid. [Online] Available: http://www.un. org/law/avl (July 30, 2013)

Electoral Institute for Democracy in Africa (EISA). 2009. 2009 National Assembly Election Results. [Online] Available: http://www.eisa. org.za/WEP/Son2009results1htm (July 29, 2009)

Electoral Institute for Democracy in Africa (EISA). 2011. South Africa: The presidency of Nelson Mandela (1994-1999). [Online] Available: http://www.eisa.org.za/WEP/souoverviews8.htm. (18 August 2011).

Ellis, S. 2014. ANC suppresses real history to boost its claims to legitimacy. [Online] Available: http://mg.co.za/article/2014-01-02-ancsuppresses-real-history-to-bo... (January 15, 2014)

Fairclough, N. 1992. Discourse and Social Change. Cambridge: Polity Press.

Fairclough, N. 2003. Analysing Discourse: Textual analysis for social research. London and New York: Routledge.

Friedman, S. 1999. No Easy Stroll to Dominance: Party dominance, opposition and civil society in South Africa. In H. Gilliomee \& C. Simkins (Eds.). The Awkward Embrace: One-party domination and democracy. Cape Town: Tafelberg.

Harris, L. 1997. Economic Objectives and Macroeconomic Constraints. In J. Michie and V. Padayachee (Eds.). The Political Economy of South Africa's Transition: Policy perspectives in the late 1990s. London: The Dryden Press, pp.91-100.

Independent Electoral Commission (IEC). 2004. National and Provincial Results 2004. [Online] Available: http://www.elections.org. za/Elections2004-static.asp?radResults=45. (June 23, 2008) 
Independent Electoral Commission (IEC). 2009. 22 April 2009 National Election Results Report. [Online] Available: http://www.elections. org.za/NPEPstaticReport/Default.aspx (July 29, 2009)

Kagarlitsky, B. 1999. New Realism, New Barbarism: Socialist theory in the era of Globalisation. London: Pluto Press.

Lodge, T. 1994. The African National Congress and its Allies. In A. Reynolds (Ed.). Elections '94 South Africa: The campaign, results and future prospects. Cape Town and Johannesburg: David Philip.

Lodge, T. 1999. Consolidating Democracy: South Africa's second popular elections. Johannesburg: Witwatersrand University Press.

McCann, P.D. \& Minichiello, V. 2010. Discourse Analysis: Effects of the researcher. In V. Minichiello \& J.A. Kottler (Eds.). Qualitative Journeys, Students and Mentor Experiences with Research. Los Angeles: Sage. pp. 219-239.

McKinley, D.T. 1997. The ANC and the Liberation Struggle: A critical political biography. London: Pluto Press.

Meredith, M. 1994. South Africa's New Era: The 1994 election. Great Britain: Mandarin Paperback.

Ndlovu'Gatsheni, S. B. 2013. Coloniality of power in post-colonial Africa: Myths of decolonisation. Dakar: CODESTRIA.

Neocosmos, M. 2008: The Politics of Fear and the Fear of Politics: Reflections on Xenophobic violence in South Africa. Journal of Asian and African Studies, 43: 586-594.

Netshitenzhe, J. 2012. Competing Identities of a National Liberation Movement versus Electoral Party Politics: Challenges of incumbency. [Online] Available: http://www.mistra.org.za/mediadocs/competing\%201ldntities.pdf (January 24, 2014)

Reynolds, A. 1994. Elections '94 South Africa: The campaigns, results and future prospects. Cape Town and Johannesburg: David Philip.

Reynolds, A. 1999. The Results. In A. Reynolds (Ed.). Election '99 South Africa: From Mandela to Mbeki. Cape Town: David Philip.

South African Concise Oxford Dictionary (SACOD). 2002. Cape Town: Oxford University Press Southern Africa.

Scruton, R. 1982. A Dictionary of Political Thought. London: Pan Books and Macmillan Press.

Terreblanche, S. 2012. Lost in Transformation: South Africa's search for a new future since 1986. Johannesburg: KMM Review Publishing Company.

The Constitution of the Republic of South Africa, Act 108 of 1996.

Webster, E \& Adler, G. 2001. Exodus Without a Map? The labour movement in a liberalizing South Africa. In B. Beckman \& L.M. Sachikonye (Eds.). Labour Regimes and Liberalization: The restructuring of state-society relations in Africa. Harare, Zimbabwe: University of Zimbabwe Publications, pp. 120-146.

Williams, W.R. 1993. Texts and Discourses: A framework for the production of meaning. In A.S. de Beer (Ed.). Mass Media for the 90's. Pretoria: Van Schaik Books, pp. 343-363. 
